$\mathrm{DOE} / \mathrm{ER} / 13883--\mathrm{Tl}$

DE92 006442

\title{
UNRAVELLING LIGNIN FORMATION AND STRUCTURE
}

(DE-FG05-88ER13883)

FINAL REPORT

\section{(April 1, 1988 - March 31, 1991)}

by

\author{
NORMAN G. LEWIS, DIRECTOR \\ Institute of Blological Chemistry \\ Washington State University \\ Pullman, WA 99164-6340
}

\section{DISCLAIMER}

This report was prepared as an account of work sponsored by an agency of the United States Government. Neither the United States Gnvernment nor any agency thereof, nor any of their employees, makes any warranty, express or implied, or assumes any legal liability or responsibility for the accuracy, completeness, or usefulness of any information, apparatus, product, or process disclosed, or represents that its use would not infringe privately owned rights. Reference herein to any specific commercial product, process, or service by trade name, trademark, manufacturer, or otherwise does not necessarily constitute or imply its endorsement, recommendation, or favoring by the United States Government or any agency thereof. The views and opinions of authors expressed herein do not necessarily state or reflect those of the United States Government or any agency thereof. 
1. Monomer Biosynthesis.

2. Monomer Transport

a. Biosynthesis of Z-Monolignol Glucosides .

b. Transport of Precursors to Site of Lignification.

3. Polymerization Process...

a Determination of Lignin Bonding Pattern In Situ.

b. Function of Specific Peroxidases in Lignin Formation

c. Role of Cell Wall-Bound Hydroxycinnamic Acids in Lignin Biosynthesis.

d. Isolation of Hydroxycinnamic Acid Hemicellulose Transferase 


\section{Summary}

During this study, we established that the Fagaceae exclusively accumulate $Z$. monolignols/glucosides, and not the E-isomers. Evidence for the presence of a novel $E \rightarrow Z$ isomerase has been obtained. The UDPG:coniferyl alcohol glucosyltransferase exhibiis a strong substrate specificity for $Z$ - (and not $E$-) monolignols. Thus, the exclusivity of $E$-monolignols in lignification no longer seems valid. The substrate specificity of UDPG:coniferyl alcohol glucosyltransferase in Pinus taeda was also examined, where only a small preference for the $E$ over the Z-isomer was observed. Consequently, proposed monolignol transport processes have been amended to accommodate the involvement of both $E$ - and $Z$-isomers. Antibodies were raised against protein conjugated with E-coniferyl alcohol, and offers the opportunity to determine the subcellular localization of this metabolite.

Our pioneering work in lignin biosynthesis and structure in situ has also progressed smoothly. W'e established the bonding environments of a woody angiosperm, Leucaena leucocephala, as well as wheat ( $T$. aestivum) and tobacco $(N$. tabacum). None of these were adequately represented by bonding environments within synthetic DHP polymers.

A cell culture system from Pinus taeda was developed which seems ideal for investigating the early stages of lignification. These cultures excrete peroxidase isozymes, considered to be specifically involved in lignin deposition.

We also studied the effect of the putative lignin-degrading enzyme, lignin peroxidase, on monolignols and dehydropolymerisates therefrom. In all cases, polymerization was observed, and not degradation; these polymers are identical to that obtained with horseradish peroxidases $/ \mathrm{H}_{2} \mathrm{O}_{2}$. It seems inconceivable that these enzymes can be considered as being primarily responsible for lignin biodegradation.

Tentative evidence for the ro!e of cell wall-bound hydroxycinnamic acids in initiating lignification was obtained, where it appears that feruloyl glucose is the moiety transferred onto the hemicellulose chain. 


\section{Introduction}

The uniqueness of the biosynthesis of lignins, compared with most other biological polymers, is that their formation takes place outside of the cell membrane in the lignifying wall. This final report describes progress made over a threa-year period in understanding three knowledgedeficient areas in lignification: (1) monomer biosynthesis; (2) monomer transport; and (3) the polymerization process. All main objectives were realized. Each topic is discussed separately below.

\section{Results}

1. Monomer Blosynthesis. It has long been considered ${ }^{1}$ that lignins from woody plants are exclusively derived from the three E-monolignols, p-coumaryl, coniferyl and sinapyl alcohols (Fig. 1), and that the ratio of each monolignol in lignins varies with species, ${ }^{1}$ subcellular compartment, ${ }^{1}$ and tissue type (e.g., normal vs. reaction wood ${ }^{2}$ ). For example, with the gymnosperm, Picea mariana, it appears that the p-coumaryl alcohol content is greatest in the middle lamella, whereas that of coniferyl alcohol is greatest in the secondary wall. ${ }^{3}$ Interestingly, the p-coumaryl alcohol content of reaction wood is also higher than its "normal" wood counterpart, as evidenced from a study of douglas fir (Pseudotsuga menziesii). ${ }^{4}$

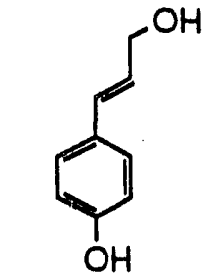

E-p-coumaryl alcohol<smiles>[R]Oc1ccc(CCCO)cc1OC</smiles>

$\mathrm{R}=\mathrm{H}: \quad E$-coniferyl alcohol $\mathrm{R}=\mathrm{Glc}: E$-coniferin<smiles>COc1cc(/C=C/CO)cc(OC)c1O</smiles>

$\mathrm{R}=\mathrm{H}: \quad E$-sinapyl alcohol $\mathrm{R}=\mathrm{Glc}: E$-syringin<smiles>COc1ccc(/C=C\CO)cc1O</smiles>

$\mathrm{R}=\mathrm{H}:$ Z-coniferyl alcohol $\mathrm{R}=\mathrm{Glc}: \mathrm{Z}$-coniferin<smiles>COc1cc(/C=C\CO)cc(OC)c1O</smiles>

$\mathrm{R}=\mathrm{H}: \quad Z$-sinapyl alcohol $\mathrm{R}=\mathrm{Glc}: Z$-syringin

Fig. 1. E- and Z-monolignols and their glucosides.

Such findings suggest that the pattern of monolignol deposition during woody plant cell wall assembly is both temporally and spatially predetermined, and a number of investigations employing radiolabeled substrates and actively-lignifying tissues have provided support to this view. $5-7$

Two distinct mechanisms have been proposed for monolignol transport from the cytoplasm through the plasma membrane and into the cell wall where lignification occurs. ${ }^{1,8}$ In the first scenario, it is envisaged that monolignols are converted into their glucosides (e.g., E-coniferin, 
E-syringin, Fig. 1) and then cross through the plasma membrane. Action of a $\beta$-glucosidase regenerates the monolignols and lignification occurs in a reaction catalyzed by peroxidase in the presence of $\mathrm{H}_{2} \mathrm{O}_{2}$. Alternatively, the monolignol glucosides may serve as storage products (e.g., in the vacuole) and are only conscripted for ligniflcation as needed. In this case, the monolignols serve as the major specles being transferred into the cell wall. Whatever the case, monolignol glucosides are assumed to play a role in the lignification process.

It should be noted that the exclusivity of $E$-monolignols and $E$-monolignol glucosides in biosynthesis, transport, and storage is incorrect. This is because (a) in Fagus grandifolia, only Z-monolignols ${ }^{1,9,10}$ and their corresponding glucosides ${ }^{9-11}$ accumulate, and the E-counterparts are absent, and (b) monolignols, such as coniferyl alcohol, are also utilized in the synthesis of the closely-related lignans, ${ }^{12-14}$ and perhaps suberin also.

The biosynthetic pathway to the Z-monolignols was investigated during this funding period, with two possibilities envisaged: (i) that $Z$-monolignols were derived from $Z$-hydroxycinnamic acids (e.g., $Z$-ferulic, $Z$-sinapic acid); and (ii) that a novel isomerase catalyzed the conversion of $E \rightarrow Z$ monolignols (e.g., coniferyl alcohol). The first possibility had literature precedence, ${ }^{8}$ since it is well-known that cell wall-bound hydroxycinnamic acids undergo $E \rightarrow Z$ photoisomerism. On the other hand, isomerization at the alcohol level had never been reported. We demonstrated that $E \rightarrow Z$ photoisomerism occurred in vitro, but only following irradiation of the monolignols (or their glucosides) with an open face mercury arc lamp, which gave mixtures of $E$ - and Z-isomers. ${ }^{15}$ Chromatographic (HPLC) conditions were developed for separation of the mixtures of $E / Z$ monolignols (and their glucosides).

This photoisomerism does not appear to occur in vivo; instead, convincing evidence for an unusual isomerase was obtained.16 The evidence for this assertion is as follows: First, radiolabeling studies with Fagus grandifolia bark tissue revealed that E-coniferyl alcohol was biochemically converted into its $Z$-isomer under conditions where $E \rightarrow Z$ photoisomerization does not occur, i.e., using a green safety light. Second, assays of cinnamyl alcohol dehydrogenase revealed that the enzyme showed a strong substrate specificity for the $E$-over its $Z$-isomer. ${ }^{16}$ Third, a crude enzyme preparation from $F$. grandifolia bark tissue, in the presence of UPD- $\alpha$ $D\left[{ }^{14} \mathrm{C}\right]$ glucose, was able to weakly catalyze the conversion of $E$-coniferyl alcohol into $Z$ coniferin. ${ }^{17}$ Taken together, these results suggest the involvement of a novel stereoselective $E \rightarrow Z$ hydroxycinnamyl alcohol isomerase.

DOE Renewal Funding (1991-94): The crude enzyme preparation capable of catalyzing $E \rightarrow Z$ is now undergoing purification (by FPLC, etc.) in order that it can be purified to apparent homogeneity, appropriately characterized, and its subcellular location determined.

2. Monomer Transport. This study focused on two areas: (a) biosynthesis of $Z$ monolignol glucosides, and (b) transport of monomeric lignin precursors to the site of lignification.

(a) Biosynthesis of Z-Monolignol Glucosides. Given the presumed role(s) of monolignol glucosides in lignification, ${ }^{1}$ it was of considerable interest to establish whether UDPG:coniferyl alcohol (CA) glucosyltransferases exhibited any substrate stereoselectivity toward either E- or Z-monolignols. Cell-free extracts prepared from the angiosperm, Fagus grandifolia, were incubated with either E- or Z-coniferyl alcohol in the presence of UDP- $\alpha-D$ $\left[U-{ }^{14} \mathrm{C}\right]$ glucose. ${ }^{17}$ After incubation, both $E$ - and Z-coniferins were added to the enzyme assay mixtures as radiochemical carriers. $E$ - and $Z$-coniferins from each incubation were then separated by high-performance liquid chromatography, individually acetylated, and recrystallized to constant radioactivity. The results are given in Table 1 , and reveal a marked 
stereoselective preference for Z-coniferyl alcohol over its E-counterpart $(5.74 \%$ vs. $<0.24 \%$ conversion, respectively).

Table 1. Stereoselectivity of $F$. grandifolia Bark UDPG:CA Glucosyltransferase.

Monolignol

Substrate
Radiochemical

Carrier
Radiochemical

Conversion (\%)

$\begin{array}{llr}Z \text {-coniferyl alcohol } & \text { E-coniferin } & 0 \\ & \text { Z-coniferin } & 5.74 \\ \text { E-coniferyl alcohol } & \text { E-coniferin } & <0.24 \\ & \text { Z-coniferin } & 0.92\end{array}$

In an analogous manner, a crude cell-free extract from the gymnosperm, Pinus taeda (loblolly pine), was prepared, and the stereoselectivity of the glucosylation reaction in coniferin synthesis was investigated. ${ }^{18}$ In this case, the glucosyltransferase preparation displayed only a slight preference for the E- (over the Z-) isomer, and both $E$ - and $Z$-monolignols were efficienty glucosylated (see Table 2).

Table 2. Stereoselectivity of $P$. taeda cambial tissue UDPG:CA glucosyltransferase.

\begin{tabular}{llc}
\hline Monolignol & $\begin{array}{c}\text { Radiochemical } \\
\text { Product }\end{array}$ & $\begin{array}{c}\text { Radiochemical } \\
\text { Conversion (\%) }\end{array}$ \\
\hline -coniferyl alcohol & $Z$-coniferin & 27.54 \\
E-coniferyl alcohol & E-coniferin & 57.52 \\
\hline
\end{tabular}

These findings reveal intriguing nuances in the stereoselectivity of UDPG:coniferyl alcohol glucosyltransiterases which were previously unknown, i.e., UDPG:CA glucosyltransferases from various sources display profoundly different specificities toward $E$ - and $Z$-monolignols. As a consequence, a revised depiction of monolignol transport and storage using either $E$ - or $Z$ monolignols is proposed in Fig. 2. These results raise a number of new questions: (a) how do glucosyltransferases from different species effect such differences in stereuselectivity?; (b) are distinct glucosyltransferases (i.e., isozymes) formed at different stages of cell wall development, and do they have differing specificities for $E$ - and Z-coniferyl and sinapyl alcohols?; (c) how efficiently are $E$ - and $Z$-monolignol glucosides transported through the plasma membrane?; (d) do the $\beta$-glucosidase(s) in the cell wall display different specificities for E- and Z-monolignol glucosides?; and (e) where are the glucosyltransferases and monolignols located in the cell? Answers to such questions will clarify many of the uncertainties surrounding monolignol transport and storage and, consequently, the lignification process itself. 


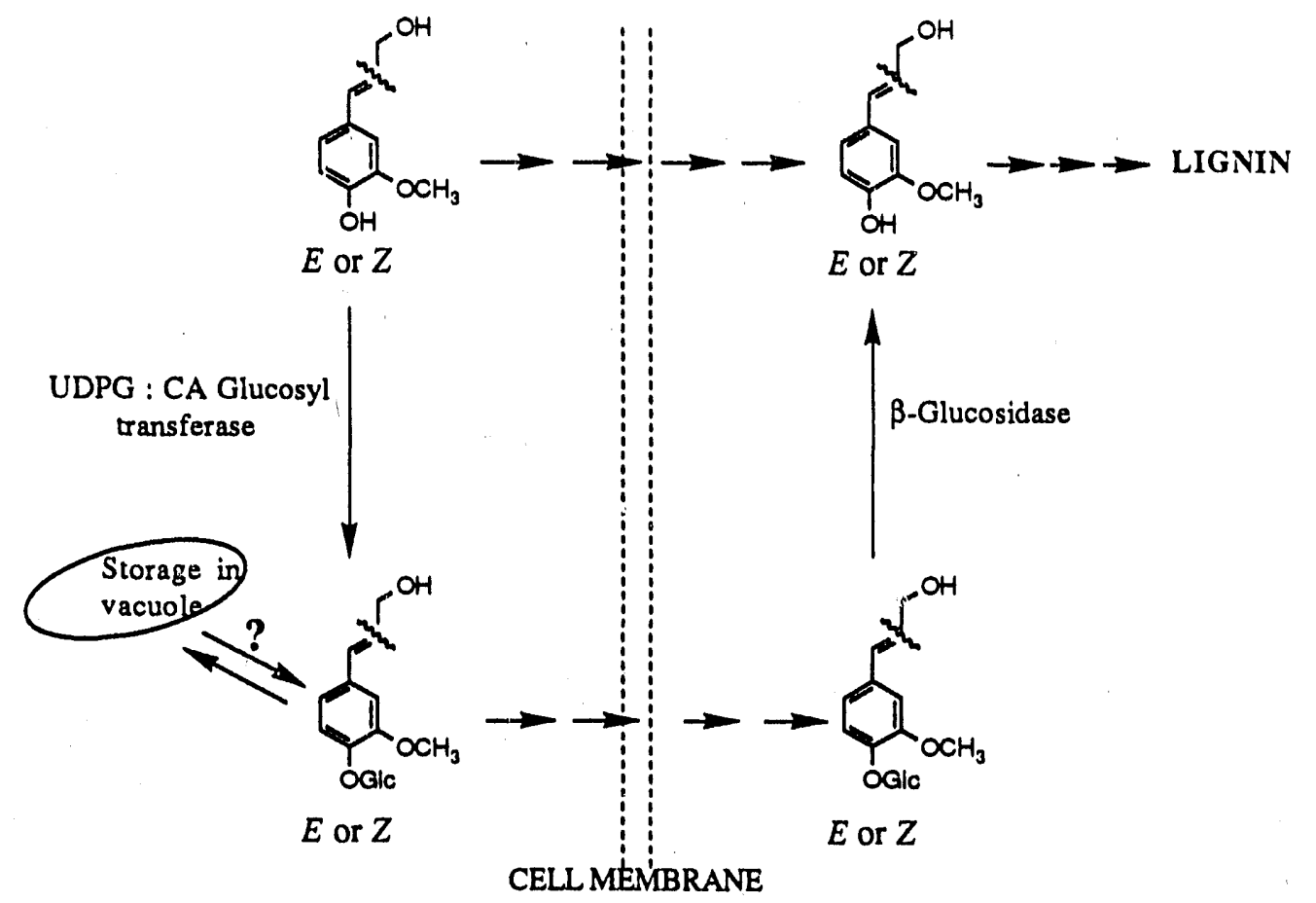

CYTOPLASM

CELL WALL

Fig. 2. Hypothetical transport and storage functions of $E$ - and $Z$ monollgnols (glucosides), such as coniferyl alcohol, in lignification.

DOE Renewal Funding (1991-94): The UDPG:E- and Z-coniferyl alcohol glucosyltransferases, affording $E$ - and $Z$-coniferins, are being purified to apparent homogeneity. This is in order to characterize the enzymes (determination of standard enzyme parameters, e.g., $\mathrm{Km}$, Vmax, etc.) as well as determining their subcellular location.

(b) Transport of Precursors to Site of Lignification. Dogma has held that E-monolignol glucosides (e.g., E-coniferin, E-syringin) are the intermediates required for monolignol transport across the cytoplasmic membrane (see ref. 8). However, this has never been proven, and the glucosides may serve only in a storage capacity. [As stated earlier, the exclusivity of $E$-monolignol glucosides can no longer be defended, given the substrate specificity of $F$. grandifolla UDPG:coniferyl alcohol glucosyltransferase for Z-coniferyl alcohol and the accumulation of Z-coniferin.]

Originally, we proposed to investigate monolignol transport, first by measuring the rate of diffusion of monolignols through liposomes, and second by incorporating ${ }^{14} \mathrm{C}$-labeled monolignols into loblolly pine protoplasts and identifying the chemical nature of the intermediates being exported into the dialyzate. We have, however, deviated substantially from the original plan and are, instead, focusing upon an immunocytochemical approach for the localization of key metabolites and enzymes. Thus, as part of an introductory background, it should be noted that the subcellular location(s) of late-stage phenylpropanoid metabolites (i.e., monolignols and monolignol glucosides) and the enzymes synthesizing such substances are unknown. Until this is rectified, our views on lignin formation can only be speculative. Determining where $E$ - and Z-monolignols (glucosides) accumulate, and where the enzymes synthesizing such metabolites are located, should provide an excellent start to deciphering synthesis, transport, storage, and regulatory processes. [For example, it will be of particular 
interest to establish. whether $E$ - and Z-monolignols differ in subcellular location (i.e., bark vs. woody xylem tissue), whether monolignol glucosides are storage products (e.g., in the vacuole) or are actively transported through the plasma membrane.] To achieve such goals, the precise subcellular location(s) of $E$ - and Z-coniferyl alcohols and their glucosides need to be determined. Similarly, the site(s) of metabolite synthesis where the enzymes, cinnamyl alcohol dehydrogenase, UDPG:E- and Z-coniferyl alcohol glucosyltransferases are located within the cell must be established. To this end, preliminary progress in establishing the location of E-coniferyl alcohol in intact tissue (or cells thereof) is described.

Coniferyl alcohol is too small a molecule (mol. wt. 180) to generate an immunogenic response in mammalian systems (e.g., rabbits) by itself. It must first be conjugated with a larger immunogenic molecule or carrier protein, such as bovine serum albumin (BSA). This was achieved by synthesis of a complex formed (see Fig. 3) between E-coniferyl alcohol and BSA (i.e., the hapten:protein conjugate) by reacting $E$-coniferyl alcohol with chloroacetic acid. The resulting acid was converted to its anhydride using dicyclohexylcarbodiimide (DCC), and subsequently covalently attached to BSA as the amide, giving a hapten:protein ratio of $21.5: 1$.

With the required E-coniferyl alcohol:BSA conjugate on hand, it was applled intradermally across the back of a rabbit in a phosphate buffer saline (PBS) solution emulsified in complete Freund's adjuvant. This procedure was repeated three times more over a one-week interval.

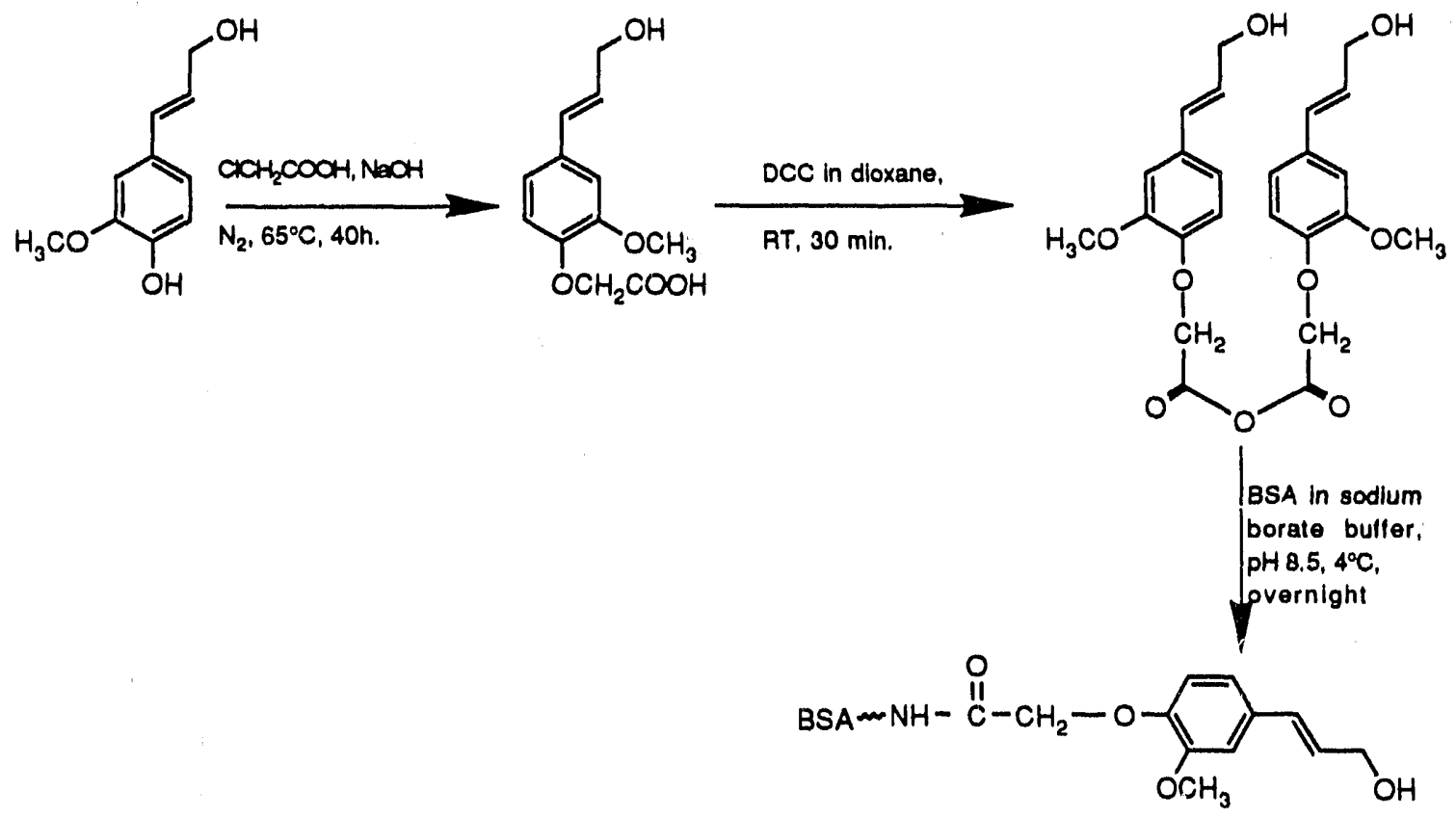

Fig. 3. Synthesis of E-coniferyl alcohol:BSA conjugate.

Two weeks after the last injection, additional conjugate was injected subcutaneously into the back of the neck. Booster injections were repeated every two weeks and the serum was tested for antibody production by dot blots ${ }^{1 \theta}$ one week after the injection. Antibodies were detected in the serum five weeks following the first injection, but the conjugate was applied to the rabbit four more times, as before, in order to increase the titer of the polyclonal antibodies.

The specificity of the antibodies raised was examined using a nurniver of compounds containing similar functionalities, i.e., to determine whether cross-reactivity was occurring. The selected compounds are given in Table 3 and include phenylpropanoid metabolites such as $Z$-coniferyl 
alcohol, coniferaldehyde, ferulic acid, sinapyl alcohol, and coniferin; cross-reactivity was determined using ELISA techniques (see ref. 19).

As can be seen from Table 3, antibodies raised against the E-coniferyl alcohol:BSA conjugate cross-react differentially with Z-coniferyl alcohol, coniferaldehyde, sinapyl alcohol, and coniferin (51 to $60 \%$ cross-reactivity) and, to a lesser extent, with ferulic acid $(9 \%)$.

Table 3. Cross-Reactivity of Anti E-Coniferyl Alcohol Serum. Crossreactivity was determined by the enzyme-linked immunosorbent assay (ELISA): The antiserum was preincubated with $E$-coniferyl alcohol or its structural analogues and further incubated with the antigen:protein conjugate immobilized on a solid phase.

Ferulic acid

In summary, the preliminary results indicate that it will be possible to obtain antibodies highly-specific to individual phenylpropanoid metabolites.

DOE Renewal Funding (1991-94): The next step is to chromatographically separate these polyclonal antibodies to obtain fractions that will specifically react with E-coniferyl alcohol, but not with the other analogues. A similar situation should hold for $Z$-coniferyl alcohol and $E$ IZ-coniferins.

3. Polymerization Process. Four areas were examined: (a) determination of bonding patterns in lignin in situ; (b) function of specific peroxidases in lignin formation; (c) role of cell wall-bound hydroxycinnamate esters in lignin biosynthesis; and (d) isolation of hemicellulose hydroxycinnamic acid ester transferase.

(a) Determination of Lignin Bonding Patterns In Situ. We have continued to 'pioneer methodology whereby lignin structure can be examined in situ, thereby affording direct examination of lignin structure and formation, ${ }^{1,20-30}$ as well as identifying the changes that the macromolecule undergoes during its removal from plant tissue. The approach taken was administration of specifically-labeled carbon-13 lignin precursors to ... ct plants actively biosynthesizing lignins over extended durations of time (weeks. months, etc.), followed by analyses by solid-state ${ }^{13} \mathrm{C}-\mathrm{NMR}$ spectroscopy. The plants examined to date include Leucaena leucocephala, wheat (Triticum aestivum I..), tobacco (Nicotiana tabacum), and loblolly pine (Pinus taeda).

Before briefly describing the results obtained, it needs to be emphasized that such labeling experiments are not trivial. Introduction of the precursor was accomplished via uptake through the root system with plants grown hydroponically on sterile medium; the medium was exchanged weekly to provide new exogenously-supplied precursor, and tests were conducted to ensure media and plant sterility, as well as establishing that the precursor had not undergone any biological conversion prior to uptake. Another important feature (in supplying exogenous 
precursors) was to verify that the normal lignification process (lignin content and monomer composition) was not adversely affected.

Of the lignin precursors examined to date, ferulic acid and phenylalanine were the most efficacious. Many of our preliminary experiments used ferulic acid, but it suffered from one major disadvantage - namely, that while efficiently taken up by the roots $(\sim 10-15 \%)$, it was not translocated into aerial portions. A minor disadvantage to using ferulic acid as a precursor was that the monomer composition of the lignin in the root tissue also changed slightly (i.e., the ratio of monolignol derived constituents (i.e., hydroxyphenyl:gualacyl:syringyl) changed from $8: 59: 33$ to $4: 65: 31$ ). This suggests that the p-coumaryl alcohol content dropped substantially. Another disadvantage was that the lignin content of the stems, as evidenced by the acetyl bromide test, dropped from $13-16 \%$ to $9.4-10 \%$. The reasons for these changes are not understood.

Administration of $[U-14 \mathrm{C}]$ phenylalanine gave better results. Uptake was again high ( 10$16 \%$ ), with most of the radioactivity (>90\%) residing in the insoluble portion (i.e., lignified cell walls). The lignin contents of roots and stems were very similar to controls (ranged from $13-16 \%)$, and the monomer composition ratios were essentially identical. More importantly, the phenylalanine was efficiently translocated throughout the plant. [Further, during all experiments, the medium was removed, checked for bacterial contamination, and the specific activity of the phonylalanine (or ferulic acid) remaining in the medium was determinad by scintillation counting. HPLC detection (for ferulic acid), and phenylalanine ammonia lyase activity (for phenylalanine).]

In the case of $L$. leucocephala, $\left[1^{-13} \mathrm{C}\right],\left[2-{ }^{13} \mathrm{C}\right]$, and $\left[3-{ }^{13} \mathrm{C}\right]$ ferulic acids and phenylalanines were individually administered to the growing plants. Following uptake and metabolism over a 2.8-day period, the plants were harvested, and the solid-state ${ }^{13} \mathrm{C}$-NMR spectra recorded. Figures $4 a$ and $4 b$ show the solid-state ${ }^{13} \mathrm{C}$-NMR spectra obtained for stem and root tissue, respectively, previously administered $\left[1-1^{13} \mathrm{C}\right]$ phenylalanine. In the stem tissue, an intense signal at $63 \mathrm{ppm}$ was observed, together with a small shoulder at $72 \mathrm{ppm}$. This demonstrated that the Phe precursor, which was originally a carboxylic acid, had undergone reduction to the monolignol (i.e., $-\mathrm{CH}_{2} \mathrm{OH}$ ), followed by subsequent polymerization. These resonances at 63 and $72 \mathrm{ppm}$ are consistent with ligrin substructures shown in Fig. 5. Similar results were obtained with root tissue, except that a small resonance was noted at $170-174 \mathrm{ppm}$, which corresponded to unconverted phenylalanine. A comparable observation was made when [1${ }^{13} \mathrm{C}$ ferulic acid was used (i.e., enhanced resonances at 63-72 and 170-174 ppm). Interestingly, when such plants were allowed to further metabolize without additional precursor, the signals at 170-174 ppm diminished, indicating that the "excess" precursor had been converted into lignin. On the other hand, when Triticum aestivum was administered [1${ }^{13} \mathrm{C}$ phenylalanine, the solid-state ${ }^{13} \mathrm{C}$-NMR spectra of the roots and stems gave large resonances at $170-174 \mathrm{ppm}$, together with a small signal at $\sim 63 \mathrm{ppm}$ (i.e., the lignified tissue in this plant was mainly derived from hydroxycinnamic acid rather than hydroxycinnamyl alcohol moieties). This is an important point and serves to distinguish between lignins from grasses and woody plants. 


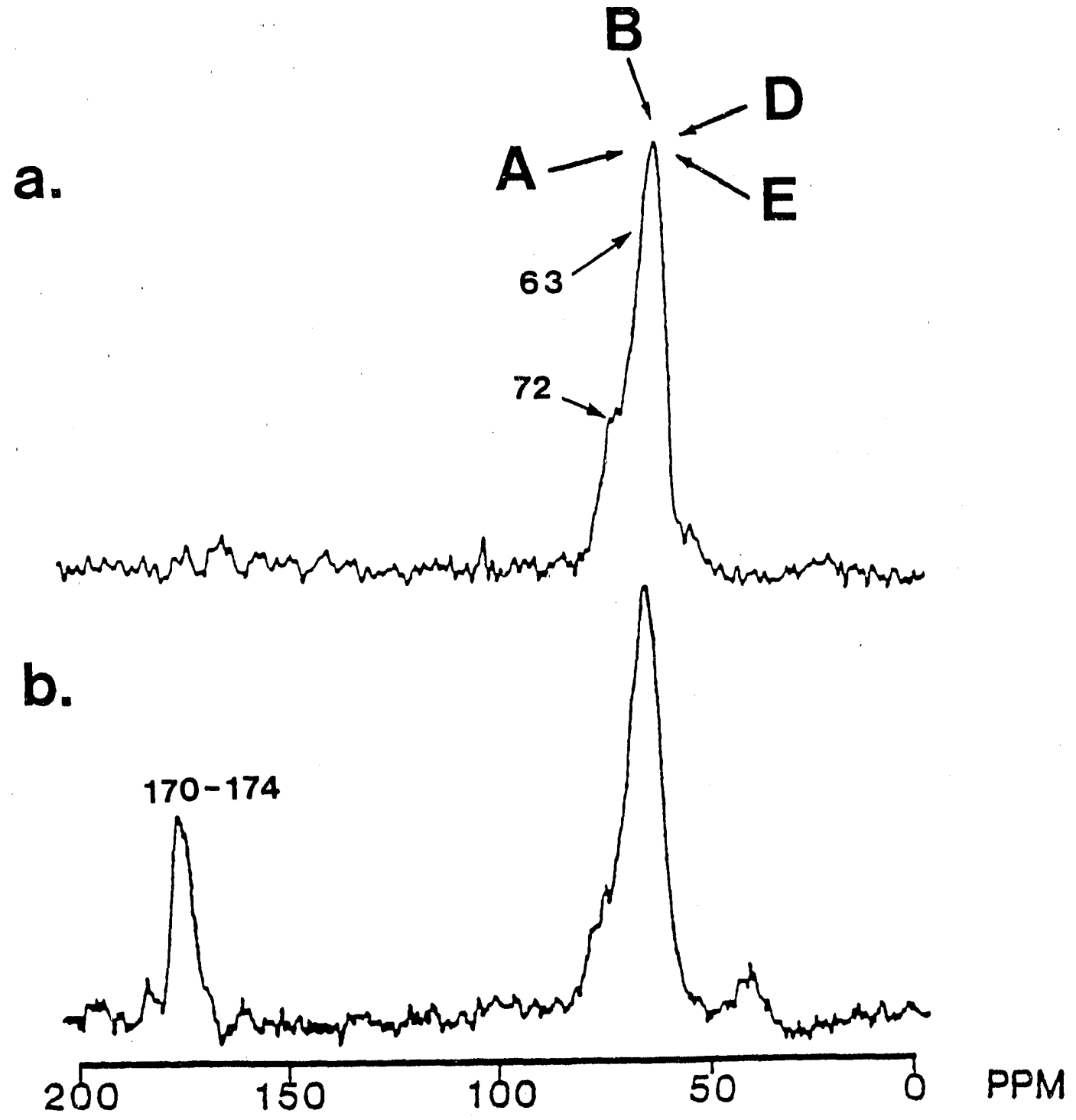

Fig. 4. Solid-state ${ }^{13}$ C-NMR spectra of L. leucocephala (a) stems, and (b) roots administered $[1-13 \mathrm{C}]$ phenylalanine 


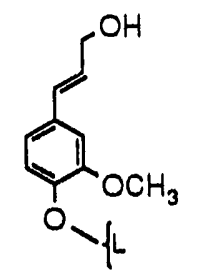

A<smiles>COc1cc(COc2c(OC)cc(C(C)CO)cc2OC)ccc1OC(C)(C)C</smiles>

D

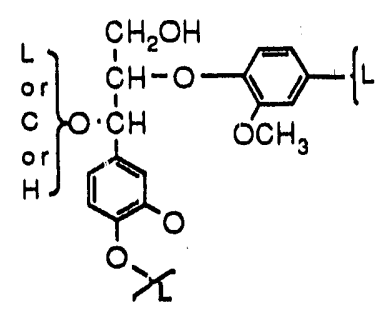

B

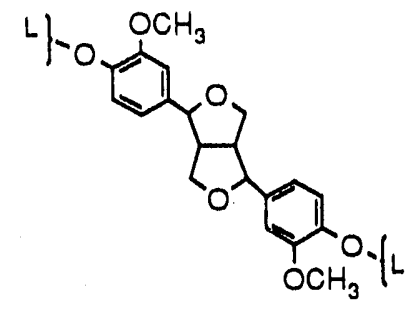

C

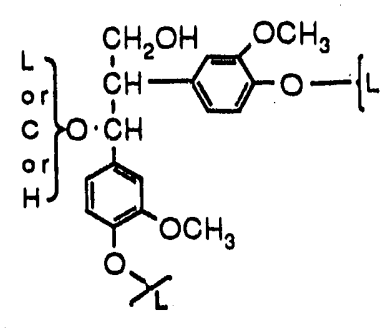

E

$$
\begin{aligned}
& L=\text { Lignin } \\
& C=\text { Carbohydrate } \\
& H=\text { Hydrogen }
\end{aligned}
$$

Fig. 5. Lignin substructure.

Next, when $[2-13 \mathrm{C}]$ phenylalanine was administered to $L$. leucocephala as before, large resonances were observed at 83 and $54-55$ ppm (Figs. $6 a$ and $6 \mathrm{~b}$ ). The large resonance at 83 $\mathrm{ppm}$ represents the first unequivocal evidence that $2-0.4^{\prime}$ linkages are dominant in woody angiosperms. The smaller signals at $54-55 \mathrm{ppm}$ are coincident with those expected for the other substructures shown. Similar observations were made with root tissue, except that the signal at 54-55 ppin was even larger due to unconverted $[2-13 \mathrm{C}]$ phenylalanine. Comparable findings were made with $\left[2-1^{3} \mathrm{C}\right]$ ferulic acid, except that a small signal at $117.4 \mathrm{ppm}$, corresponding to the labeled precursor, was still evident. In contrast, $T$. aestivum again gave different results when administered $\left[2-{ }^{13} \mathrm{C}\right]$ phenylalanine; only enhanced resonances at 115 , 73 and 56 pprn were observed. None of these are attributed to the 2-0-4' bonding environment present in $L$. leucocephala and, hence, the types of linkages between monomeric units in the lignin of $T$. aestivum await clarification.

Finally, with $\left[3-{ }^{13} \mathrm{C}\right] \mathrm{Phe}$, large resonances in stem tissue were evident at 83 and $74 \mathrm{ppm}$, together with a small signal at $38 \mathrm{ppm}$ (Fig. 7a). With root tissue, this latter resonance was of greater intensity (Fig. $7 \mathrm{~b}$ ). On the other hand, when $\left[3-{ }^{13} \mathrm{C}\right]$ ferulic acid was administered, the resulting plant tissue only had signal enhancements at 83 and $74 \mathrm{ppm}$, with a small resonance at $170-174 \mathrm{ppm}$. No resonance at $38 \mathrm{ppm}$ was observed. This is interpreted as follows. First, the resonance at $83 \mathrm{ppm}$ is unequivocal evidence for lignin-carbohydrate bonding, a feature previously difficult to prove due to chemical iability on isolation. Second, the signal at $74 \mathrm{ppm}$ is consistent with that expected for $2-0-4^{\prime}$ and $2-C^{\prime}$, substructures. Third, the resorance at $38 \mathrm{ppm}$ is considered due to excess precursor (i.e., Phe). With $T$. aestivum, large signals were also observed at 83 and $74 \mathrm{ppm}$, although the nature of the bonding environments needs to be established.

We have also been conducting additional labeling experiments and, in so doing, departed substantially from the original plan. Two biological tissues are examined, namely actively lignifying cell suspension culture of loblolly pine (Pinus taeda) and $F$. grandifolia bark tissue. Conditions for converting unlignified $P$. taeda suspension cells (grown on $11.3 \mu \mathrm{M} 2,4-D$ ) to actively lignifying cells (grown on $11.3 \mu \mathrm{M}$ NAA) were identified. When this change of growth hormone was made, the primary cell walls expand, cell wall thickening occurs, and active 


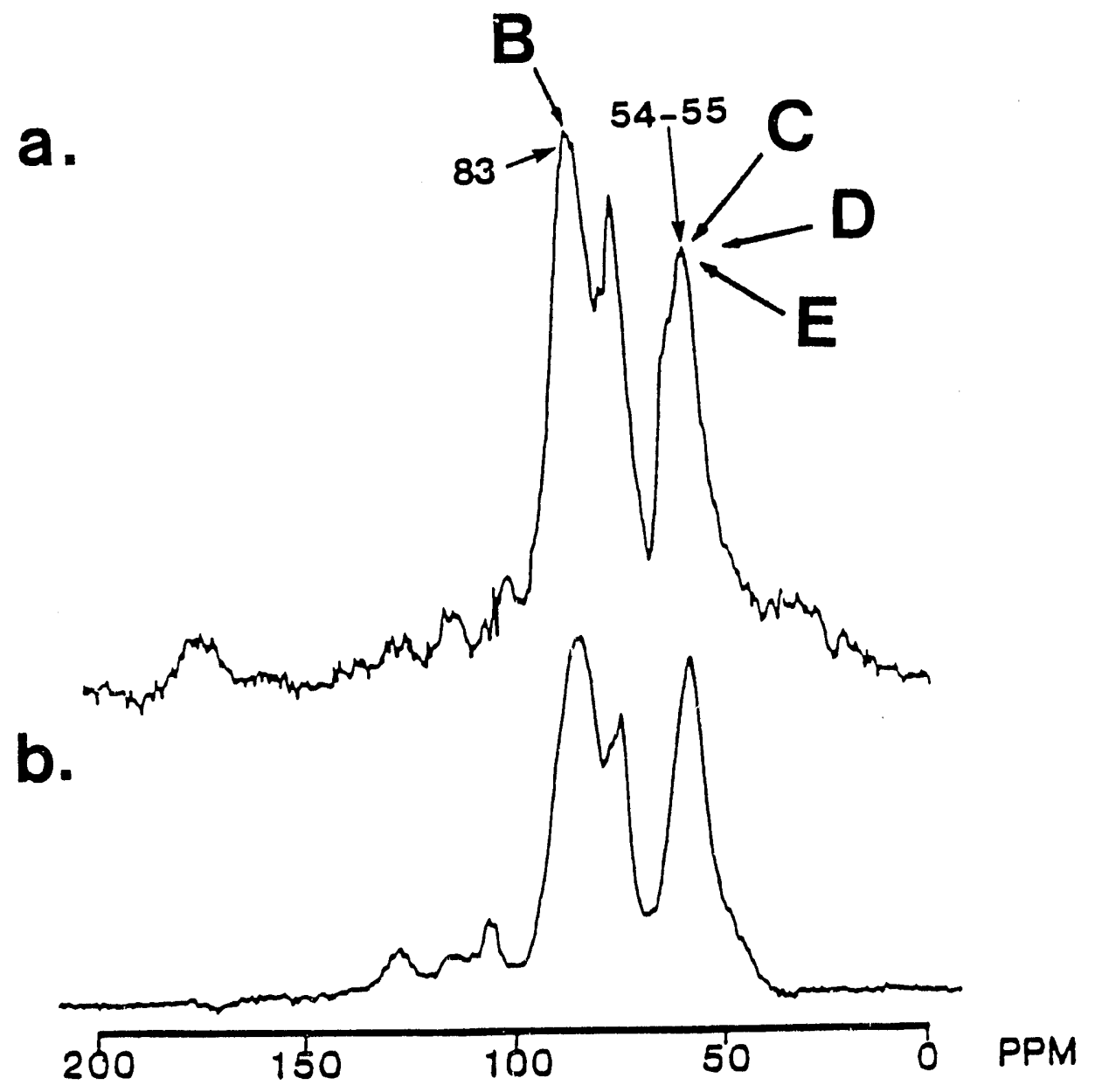

Fig. 6. Solid-state ${ }^{13}$ C-NMR spectra of L. leucocephala (a) stems, and (b) roots administered $[2-13 \mathrm{C}-$ phenylalanine 


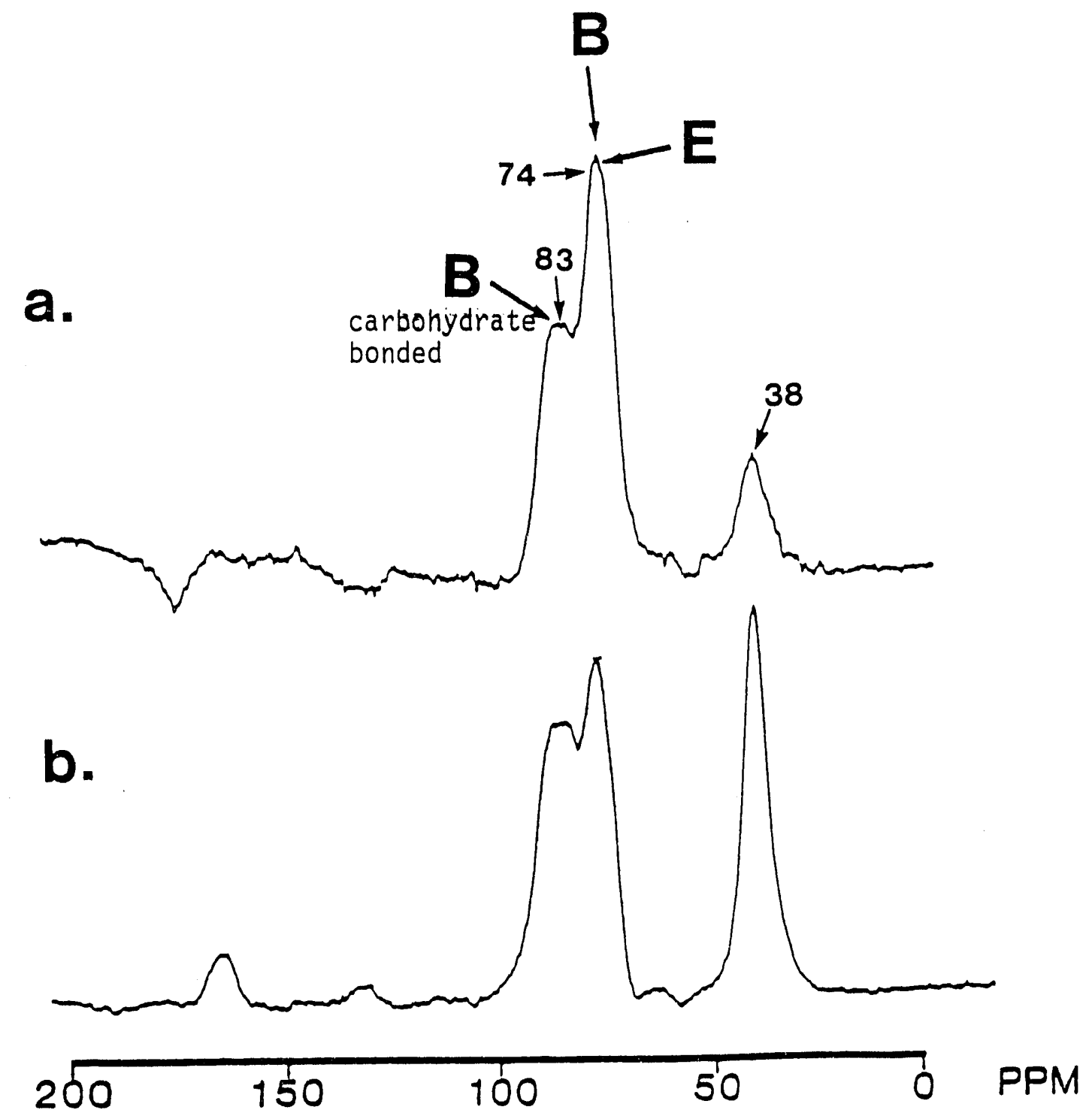

Fig. 7. Solid-state ${ }^{13}$ C-NMR spectra of L. leucocephala (a) stems, and (b) roots administered $\left[3^{-13} \mathrm{C}\right] \mathrm{phenylalanine}$ 
lignification follows. This is evidenced by an acetyl bromide lignin content of $9.9 \%,{ }^{13} \mathrm{C}-\mathrm{NMR}$ spectroscopy, histological staining, and enzyme assays. Interestingly, when these cells are first grown on 2,4-D, two peroxidase isozymes and a $\beta$-glucosidase are excreted into the nutrient medium, even though no substantial lignification occurs. Additionally, certain enzymes required for lignin formation can be detected within the cells (e.g., cinnamyl alcohol dehydrogenase), but phenylalanine ammonia lyase (PAL) cannot, suggesting a key control point. On switching to medium containing NAA, PAL activity is switched on and lignification then occurs. Thus, these cultures provide us with a unique system to investigate the bonding environments of a gymnosperm lignin in culture, l.e., during early stages of lignin deposition (renewal DOE funding).

Bark Lignin. There are very few reports about lignin in bark tissue. Of interest is whether beech bark lignin is derived from $E$ - or $Z$-coniferyl alcohol. Thus, the following experiments were devised and the results obtained. First, we recorded and interpreted the ${ }^{1} \mathrm{H}-,{ }^{13} \mathrm{C}$-, and appropriate 2-D-NMR spectra of both natural abundance monolignols. Upon comparison, significant differences for resonances of certain carbons were observed, l.e., E-coniferyl alcohol had signals at $61.6\left(C_{1}\right), 127.4\left(C_{2}\right), 109.5\left(C_{2}^{\prime}\right)$ and $119.3\left(C_{6}^{\prime}\right)$ ppm, whereas $Z$ coniferyl alcohol resonances were at $58.2\left(C_{1}\right), 130.99\left(C_{2}\right), 112.9\left(C_{2}^{\prime}\right)$, and $121.57\left(C_{6}^{\prime}\right)$. Each monolignol was then converted into its dehydrogenative polymerisate (DHP), following treatment with horseradish peroxidase $/ \mathrm{H}_{2} \mathrm{O}_{2}$. Significant differences were observed between the two preparations; the DHP from E-coniferyl alcohol had resonances at $61.6\left(C_{1}\right), 128.1$ $\left(C_{2}\right), 110.7\left(C_{2}^{\prime}\right)$, and $119\left(C_{6}^{\prime}\right)$, whereas that from Z-coniferyl alcohol gave signals at 58.1, $60.17\left(C_{1}\right), 131.4\left(C_{2}\right), 110.69 / 113.4\left(C_{2}^{\prime}\right)$, and $\sim 121\left(C_{6}^{\prime}\right)$. Thus, like the monolignols, both DHPS are readily distinguishable. This is mainly due to the presence of significant quantities of the $E$ - or $Z$-monolignols linked via their phenolic groups (i.e., the stereochemistry of the side-chain remained intact). We also isolated an acetylated m'lled wood lignin (from beech bark tissue) and examined its ${ }^{13} \mathrm{C}$-NMR spectrum. This spectrur sugges $\$ 3$ that both $E$ - and $Z$-bonding environments are present.

(b) Function of Specific Peroxidases in Lignin Formation. This particular problem has only just begun to be tackled, and $P$. taeda cell suspension cultures are being utilized. These cultures excrete two peroxidase enzymes into the medium, which are assumed to be required for lignification (when grown on 2,4-D). Time-course experiments revealed that maximum peroxidase activity occurs after nine days.

DOE Renewal Funding (1991-94): Cultures are being continually grown in order to obtain sufficient amounts of peroxidases for appropriate characterization. With cells grown on 11.3 $\mu \mathrm{M} N A A$, antibodies need to be obtained in order to establish their subcellular location in the cell wall.

Lignin Peroxidases. With specifically carbon-13 enriched lignified tissues from $L$. leucocephala, etc., on hand, it was our original intention to subject these to biological delignification by treatment with the putative lignin-degrading enzyme, lignin peroxidase. This was in order to identify the changes that occurred to the macromolecule at individual side-chain carbons, $C_{1}, C_{2}$, and $C_{3}$. This work was not undertaken as such due to conflicting reports in the literature regarding the exact properties of the enzymes (i.e., a controversy had ensued about whether lignin peroxidase, in the presence of $\mathrm{H}_{2} \mathrm{O}_{2}$, catalyzed further polymerization [rather than depolymerization] of isolated lignins).

We, therefore, undertook ${ }^{31}$ to examine whether $[1-13 \mathrm{C}],[2-13 \mathrm{C}]$, or $[3-13 \mathrm{C}]$ coniferyl alcohols, when treated with lignin peroxidase $/ \mathrm{H}_{2} \mathrm{O}_{2}$ at $\mathrm{pH} 4.0$, would catalyze the formation of a dehydropolymerisate, or whether degradation would occur. Thus, each monolignol was treated with lignin peroxidase $/ \mathrm{H}_{2} \mathrm{O}_{2}$, and in every case a quantitative yield of a polymeric product was 
obtained, which was arguably identical to that of synthetic DHPs obtained by treatment of coniferyl alcohol with horseradish peroxidase (HRP) $/ \mathrm{H}_{2} \mathrm{O}_{2}$. Importantly, the ${ }^{13} \mathrm{C}-\mathrm{NMR}$ spectrum of each polymerisate had the same resonances as that obtained with $\mathrm{HRP}_{\mathrm{H}} \mathrm{H}_{2} \mathrm{O}_{2}$, although the relative intensities varied slightly. That is, the same bonding environments were produced following treatment of monolignols with either lignin peroxidase or horseradish peroxidase, in the presence of $\mathrm{H}_{2} \mathrm{O}_{2}$. Additionally, subsequent treatment of a polymerisate with lignin peroxidase $/ \mathrm{H}_{2} \mathrm{O}_{2}$ only catalyzed the formation of a higher molecular weight polymer.

From this study, we have concluded that lignin peroxidase $/ \mathrm{H}_{2} \mathrm{O}_{2}$ cannot play a central role in lignin biodegradation.

(c) Role of Cell Wall-Bound Hydroxycinnamic Acids in Lignin Biosynthesis. In the original proposal, we envisaged that cell wall-bound hydroxycinnamic acids could function as "anchors" for lignification to occur. We proposed, at that time, to administer $[1-13 \mathrm{C}]$ phenylalanine or ferulic acid over a two- to three-week period, to $T$. aestivum, and then to allow the plant to metabolize further for one to two weeks. This was in order to determine whether bound hydroxycinnamic acids were involved in "anchoring" lignin or not. If the hydroxycinnamic acids were completely reduced to the corresponding monolignol, then such a proposal would be incorrect. However, administration of $\left[1-{ }^{13} \mathrm{C}\right]$ phenylalanine or ferulic acid gave lignified plant tissue with enhanced resonances at $170-174 \mathrm{ppm}$ (i.e., the carboxylic functionalities were essentially not reduced). Thus, it would appear that not only are cell wall-bound hydroxycinnamic acids involved in lignification, but also that the lignin itself is derived, to a large extent, by polymerization of hydroxycinnamic acids (e.g., ferulic acid). On the other hand, when a similar experiment was carried out with the woody anglosperm, L. leucocephala, further metabolism for an additional seven days resulted in essential depletion of the carboxylic acid resonances at $\sim 170-174 \mathrm{ppm}$. Thus, in this case, if hydroxycinnamic acids are involved as "anchors" as proposed, they are only present to the extent of bordering upon the detection limits of the experimental methodology employed.

(d) Isolation of Hydroxycinnamic Acid Hemicellulose Transferase. It is well established that many grasses contain hemicelluloses having cell wall-bound hydroxycinnamic acids covalently linked to esters. We have attempted to isolate the enzyme responsible for this coupling, and to establish the precursor for this attachment. Both [2${ }^{14} \mathrm{C}$ feruloyl glucose and feruloyl CoA were individually incubated with cell-tree preparations from barley, and also with the insoluble pellet remaining after removal of the soluble enzymes. Our experiments to date suggest (but do not prove) that feruloyl glucose is the precursor, and that the enzyme involved is present in the insoluble pellet. 


\section{Literature Cited}

1. Lewis, N.G. and Yamamoto, E. 1990. Lignins: Occurrence, Blosynthesis and Blodegradation. Ann. Rev. Plant Physiol. Mol. Biol. 41:455

2. Timell, T.E. 1986. Compression Wood in Gymnosperms. Vol. 1, Springer-Verlag, Berlin, Heidelberg, 706 pp.

3. Whiing, P. and Goring, D.A.I. 1982. Chemical Characterization of Tissue Fractions from the Middle Lamella and Secondary Wall of Black Spruce Tracheids. Wood Sci. Technol. 16:261.

4. Latif, M.A. 1968. Comparative Study of Normal and Compression Wood. Lignin of Douglas Fir (Pseudotsuga menziesii) Franco, Ph.D. Thesis, University of Washington, Seattle, $69 \mathrm{pp}$.

5. Terashima, N., Fukushima, K. and Takabe, K. 1986. Heterogeneity in Formation of Lignin. VIII. An Autoradiographic Study on the Formation of Gualacyl and Syringyl Lignin in Magnolia kobus DC. Holzforschung 40s:101.

6. Terashima, N. 1989. An Improved Radiotracer Method for Studying Formation and Structure of Lignin. In "Plant Cell Wall Polymers, Biogenesis and Biodegradation" (Lewis, N.G. and Paice, M.G., eds.), ACS Symp. Ser. 3999:148.

7. Fukushima, K. and Terashima, N. 1991. Heterogeneity in Formation of Lignin. XIV. Formation and Structure of Lignin in Differentiating Xylem of Ginkgo biioba. Holzforschung 45:87.

8. Yamamoto, E., Bokelman, G.H. and Lewis, N.G. 1989. Phenylpropanoid Metabolism in Cell Walls. In "Plant Cell Wall Polymers, Biogenesis and Biodegradation" (Lewis, N.G. and Paice, M.G., eds.), ACS Symp. Ser. 399:68.

9. Morelli, E., Rej, R.N., Lewis, N.G., Just, G. and Towers, G.H.N. 1986. Cis-Monolignols in Fagus grandifolia and Their Possible Involvement in Lignification. Phytochemistry $25: 1701$.

10. Harmatha, J., Lübke, H., Rybarik, I. and Măhdalik, M. 1977. Cis-Coniferyl A.lcohol and its Glucoside from the Bark of Beech (Fagus silvatica L.). Collect. Czech. Chem. Commun. $43: 774$.

11. Lewis, N.G., Inciong, Ma.E.J., Ohashi, H., Towers, G.H.N. and Yamamoto, E. 1988. Exclusive Accumulation of Z-Isomers of Monolignols and Their Glucosides in Bark of Fagus grandifolia. Phytochemistry 17:2119.

12. Umezawa, T., Davin, L.B., Yamamoto, E., Kingston, D.G.I. and Lewis, N.G. 1990. Lignan Blosynthesis in Forsythia species. J. Chem. Soc. Chem. Commun. 1405.

13. Umezawa, T., Davin, L.B. and Lewis, N.G. 1990. Formation of the Lignan, (-)-Secoisolariciresinol, by Cell-Free Extracts of Forsythia intermedia. Biochem. Biophys. Res. Commun. 171:1008.

14. Umezawa, T., Davin, L.B. and Lewis, N.G. 1991. Formation of (-)-Matairesinol and (-)-Secoisolariciresinol in Forsythia intermedia. J. Biol. Chem. 266:10210. 
15. Lewis, N.G., Inciong, Ma.E.J., Dhara, K.P. and Yamamoto, E. 1989. High-Performance Llquid Chromatographic Separation of $E$ - and Z-Monolignols and Their Glucosides. J. Chromatogr. 479:345.

16. Lewis, N.G., Dubelsten, P., Eberhardt, T.L., Yamamoto, E., and Towers, G.H.N. 1987. The $E / Z$ Isomerization Step in the Blosynthesis of Z-Coniferyl Alcohol in Fagus grandifolia. Phytochemistry 26:2729.

17. Yamamoto, E., Inciong, Ma.E.J., Davin, L.B. and Lewis, N.G. 1990. Formation of CisConiferin in Cell.Free Extracts of Fagus grandifolia Ehrh Bark. Plant Physiol. 94:209.

18. Inciong, Ma.E.J., Davin, L.B., Sederoff, R.R. and Lewis, N.G. (to be published)

19. Harlow, E. and Lane, D. 1988. Antibodies, a Laboratory Manual. Cold Spring Harbor Laboratory, $726 \mathrm{pp}$.

20. Lewis, N.G., Razal, R.A., Dhara, K.P., Yamamoto, E., Bokelman, G.H., Yamamoto, E. and Wooten, J.B. 1988. Incorporation of $\left[2-{ }^{13} \mathrm{C}\right]$ Ferulic. Acid, a Lignin Precursor, Into Leuceana leucocephala and its Analysis by Solid-State ${ }^{13} \mathrm{C}-\mathrm{NMR}$. J. Chem. Soc. Chem. Commun. 1626.

21. Lewis, N.G., Razal, R.A., Yamamoto, E., Wooten, J.B. and Bokelman, G.H. 1989. Carbon13 Specific Labeling of Lignin in Intact Plants. In "Plant Cell Wall Polymers, Biogenesis and Biodegradation" (Lewis, N.G. and Paice, M.G., eds.), ACS Symp. Ser. 399:169.

22. Lewis, N.G., Razal, R.A., Yamamoto, E., Bokelman, G.H. and Wooten, J.B. Determination of the Bonding Patterns of the Phenylpropanoid Side Chain of Lignin in Leuceana leucocephala. J. Amer. Chem. Soc. (submitted).

23. Lewis, N.G. 1988. Lignin Biosynthesis, Biodegradation and Utilization. Bull. Liaison. Groupe Polyphénols 14:398.

24. Lewis, N.G., Razal, R.A., Yamamoto, E. and Wooten, J.B. Metabolism of $[1-13 \mathrm{C}]$, $\left[2-{ }^{13} \mathrm{C}\right]$, and $\left[3-{ }^{13} \mathrm{C}\right]$ Phenylalanines into Lignin in $T$. aestivum and $N$. Tabacum (to be submitted).

25. Lewis, N.G., Luthe, C.E. and Eberhardt, T.L. 1988. Developing New Methodology to Determine Changes to the Lignin Macromolecule During Delignification. TAPPI 71:141.

26. Lewis, N.G., Inciong, Ma.E., Davin, L.B., Wise, S.A. and Razal, R.A. 1990. Monolignol Biosynthesis, Lignin Structure and Biodegradation. Bull. Liaison Groupe Polyphénols $15: 365$.

27. Lewis, N.G. 1992. In "Antioxidants in Higher Plants" (Hess, J.L. and Alscher, R., eds.), CRC Press.

28. Lewis, N.G. and Davin, L.B. 1992. Biosynthesis and Structure of Lignins, Lignans and Neolignans. In "Recent Advances in Phytochemistry" (Stafford, H.A., ed.), Plenum Press, pp. $x \times x x$.

29. Eberhardt, T.L., Davin, L.B., Yamamoto, E., Mott, R.L., Wooten, J.B. and Lewis, N.G. 1991. Lignification in Cell Suspension Cultures of Pinus taeda: Incorporation of $[1-13 \mathrm{C}],\left[2-{ }^{13} \mathrm{C}\right]$ and $\left[3^{-13} \mathrm{C}\right] \mathrm{Phenylalanines}$ (submitted). 
30. Lewis, N.G. 1991. Lignification in Plants. Bloscience $x x x x$.

31. Sarkanen, S., Razal, R.A., Piccariello, T., Yamamoto, E. and Lewis, N.G. 1991. Lignin Peroxidase: Toward a Clarification of its Role In Vivo. J. Biol. Chem. 266:3636. 


\section{Publications Attributablis to DOE Funding}

1. Lewis, N.G. 1988. Lignin Biosynthesis, Eliodegradation and Utilization. Bull. Liaison Groupe Polyphénols 14:398.

2. Lewis, N.G., Inciong, M.E.J., Ohashi, H., Yamamoto, E. and Towers, G.H.N. 1988. Exclusive Accumulation of Z-Isomers of Monolignols and Their Glucosides in Bark of Fagus grandifolia. Phytochemistry 27:(7):2119.

3. Lewis, N.G., Luthe, C.E. and Eberhardt, T.L. 1988. Developing New Methodology to Determine Changes to the Lignin Macromolecule During Delignification. TAPPI $71(1): 141$.

4. Lewis, N.G., Razal, R.A., Dhara, K.P., Yamamoto, E., Bokelman, G.H. and Wooten, J.B. 1988. Incorporation of $\left[2-1^{3} \mathrm{C}\right]$ Ferulic Acid, a Lignin Precursor, into Leuceana leucocephala and its Analysis by Solid State ${ }^{13} \mathrm{C}-\mathrm{NMR}$. J. Chem. Soc. Chem. Commun., pp. $1626-1628$.

5. Lewis, N.G., Inciong, M.E.J., Dhara, K.P. and Yamamoto, E. 1989. High Performance Liquid Chromatographic Separation of $E$ - and Z-Monolignols and Their Glucosides. J. Chrom. $47(2): 345$.

6. Lewis, N.G. and Paice, M.G. 1989. Editors of Plant Cell Wall Polymers: Biogenesis and Biodegradation. ACS Symp. Ser. 399:676.

7. Lewis, N.G., Razal, R.A., Yamamoto, E., Wooten, J.B. and Bokelman, G.H. 1989. Carbon13 Specific Labeling of Lignin in Intact Plants. In "Biosyrithesis and Biodegradation of Plant Cell Wall Polymers" (Lewis, N.G. arid Paice, M.G., eds.), ACS Symp. Ser. $399: 169$.

8. Lewis, N.G. and Yamamoto, E. 1989. Condensed Tannins: Their Place in Plant Metabolism. In "Chemistry and Significance of Condensed Tannins" (Hemingway, R.W. and Karchesy, J.J., eds.), Plenum Press, pp. 23.47.

9. Yamamoto, E., Bokelman, G.H. and Lewis, N.G. 1989. Phenylpropanoid Metabolism in Plant Cell Wails. In "Biosynthesis and Biodegradation of Plant Cell Wall Polymers" (Lewis, N.G. and Paice, M.G., eds.), ACS Symp. Ser. 399:68.

10. Lewis, N.G., Inciong, Ma.E., Davin, L.B., Wise, S.A. and Razal, R.A. 1990. Monolignol Biosynthesis, Lignin Structure and Biodegradation. Bull. Liaison Groupe Polyphénols $15: 365$.

11. Lewis, N.G. and Yamamoto, E. 1990. Lignins: Occurrence, Biosynthesis and Biodegradation. Ann. Rev. Plant Phys. and Plant Mol. Biol. 41:455.

12. Yamamoto, E., Inciong, M.E.J., Davin, L.B. and Lewis, N.G. 1990. Formation of CisConiferin in Cell-Free Extracts of Fagus grandifolia Ehrh Bark. Plant Physiol. 94:209.

13. Sarkanen, S., Razal, R.A., Piccariello, T., Yamamoto, E. and Lewis, N.G. 1991. Lignin Peroxidase: Toward a Clarification of its Role In Vivo. J. Biol. Chem. 266:3636.

14. Lewis, N.G. 1992. In "Antioxidants in Higher Plants" (Hess, J.L. and Alscher, R., eds.), CRC Press. 
15. Lewis, N.G. 1991. Methods for Separation and Identification of Low Molecular Mass Lignin Fragments and Model Compounds. Chapter VIII (HPLC). In "Methods in Lignin Chemistry" (Dence, C.W. and Lin, S.Y., eds.), Springer-Verlag (xxxx).

16. Lewis, N.G. and Davin, L..B. 1991. Blosynthesis and Structure of Lignins, Suberins, Lignans and Neolignans. In "Recent Advances in Phytochemistry" (Stafford, H.A., ed.), Plenum Press, pp. $x x x x$.

17. Lewis, N.G., Razal, R.A., Yamamoto, E., Bokelman, G.H. and Wooten, J.B. Determination of the Bonding Patterns of the Phenylpropanoid Side Chain of Lignin in Leuceana leucocephala. J. Amer. Chem. Soc., submitted.

18. Eberhardt, T.L., Davin, L.B., Yamamoto, E., Mott, R.L., Wooten, J.B. and Lewis, N.G. 1991. Lignification in Cell Suspension Cultures of Pinus taeda: Incorporation of $\left[1-{ }^{13} \mathrm{C}\right],\left[2-{ }^{13} \mathrm{C}\right]$ and $\left[3^{-13} \mathrm{C}\right]$ Phenylalanines, submitted.

19. Lewis, N.G. and Davin, L.BI 1992. Stereoselectivity in Polyphenol Biosynthesis. In "Plant Polyphenols: Biogenesis, Properties and Significance (Hemingway, R.W. and Laks, P.E., eds.), Plenum Press, xxxx. 

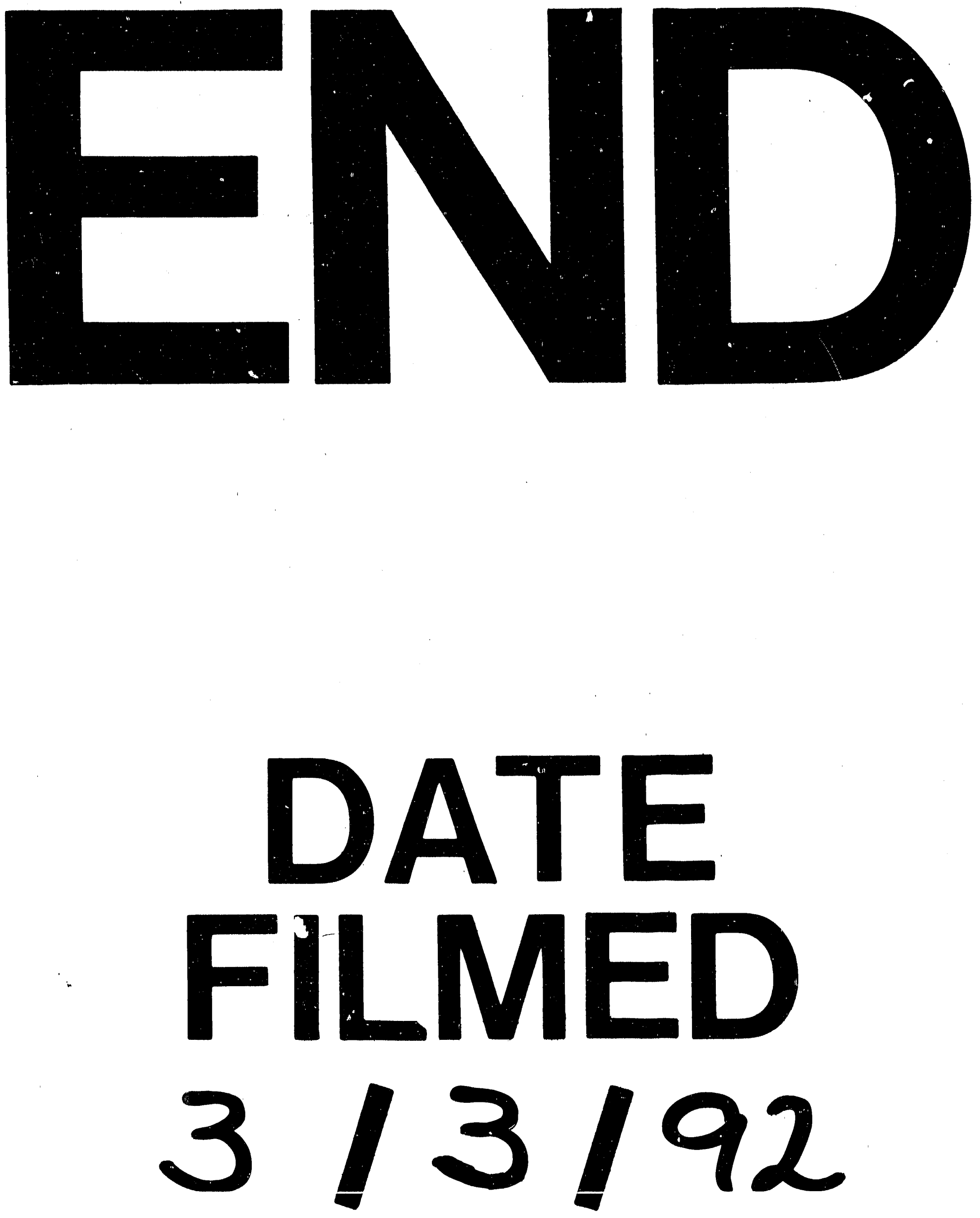
